\title{
Population trends and current status of the endangered Pyrenean sculpin Cottus hispaniolensis in the Spanish part of the Garonne drainage
}

\author{
Rafel Rocaspana ${ }^{1}$ and Enric Aparicio ${ }^{2, *}$ \\ ${ }^{1}$ Gesna Estudis Ambientals, Prat de la Riba 51, 25240 Linyola, Catalonia, Spain \\ 2 GRECO, Institute of Aquatic Ecology, University of Girona, 17071 Girona, Catalonia, Spain
}

\begin{abstract}
The status of Pyrenean sculpin Cottus hispaniolensis was assessed in the Spanish part of the Garonne drainage on the basis of its distribution and abundance from 2001 to 2016. Population trends showed a progressive reduction in range extension and density, exacerbated by a severe spate occurred in 2013. However, $C$. hispaniolensis was resilient to this natural disturbance by compensating for mortality with increasing recruitment. Both occurrence and density of Pyrenean sculpin showed a positive correlation with coarse substrates. Riverine habitat deterioration, mainly channelization, presence of dams and flow regulation are the main factors threatening sculpin populations. Several management measures are proposed.
\end{abstract}

Keywords: abundance / catastrophic spate / conservation measures / Cottus hispaniolensis / Garonne

Résumé - Tendances et état actuel de la population du chabot pyrénéen menacé Cottus hispaniolensis dans la partie espagnole du bassin de la Garonne. Le statut du chabot pyrénéen Cottus hispaniolensis a été évalué dans la partie espagnole du bassin de la Garonne sur la base des données de distribution et d'abondance au cours de la période 2001-2016. Les tendances de la population ont montré un déclin progressif de l'extension de répartition et de la densité, exacerbé par une crue sévère survenue en 2013. Cependant, $C$. hispaniolensis a montré une résilience à ce type de perturbation naturelle en compensant la mortalité par un recrutement accru. L'occurrence et la densité du chabot pyrénéen ont montré une corrélation positive avec les substrats grossiers. La détérioration des habitats rivulaires, principalement la canalisation des cours d'eau, la présence de barrages et la régulation des débits, sont les principaux facteurs potentiels qui menacent les populations de chabots. Plusieurs actions de gestion sont proposées.

Mots clés : abondance / crue catastrophique / Mesures de conservation / Distribution

The sculpins (Cottus sp., Cottidae, Scorpaeniformes) are small benthic-dwelling freshwater fish species that occur mainly in cold, well-oxygenated mountain streams and lakes (Tomlinson and Perrow, 2003). In Spain, two native sculpin species with a very restricted distribution are found (Doadrio et al., 2011): Adour sculpin Cottus aturi (Freyhof, Kottelat and Nolte, 2005) and Pyrenean sculpin Cottus hispaniolensis Băcescu and Băcescu-Meşter, 1964. The latter is endemic to the Garonne River basin (south west France and northern Spain) restricted to the southern (upper) part of the drainage in the Pyrenees (Freyhof et al., 2005).

The source of the Garonne River is located in the Val d'Aran (Catalonia, Spain), and flows for ca. $40 \mathrm{~km}$ before entering to France. Fish assemblages in the Spanish part of the drainage are almost exclusively composed of Pyrenean sculpin

\footnotetext{
* Corresponding author: enric.aparicio@gmail.com
}

and brown trout Salmo trutta L. 1758, and the introduced minnow Phoxinus sp. and Alpine charr Salvelinus umbla (L. 1758) are found in a few reservoirs and high mountain lakes (Aparicio, 2015). Pyrenean sculpin historically occurred in continuous populations located in the main course of the Garonne River and the lower parts of some tributaries (de Sostoa et al., 1990; Doadrio et al., 2011). These populations are declining in relation to historical information, but available quantitative data is scarce (Doadrio et al., 2011; Sousa-Santos et al., 2014). Pyrenean sculpin is currently listed as Critically Endangered in the Spanish and Catalan Red Lists of Threatened Species (Doadrio et al., 2011; Aparicio et al., 2016) and, as Cottus gobio (former synonym), is also included in Annex II of the European Habitats Directive 92/43/EEC. In France, there is no available information on its status, and is included as Data Deficient in the French Red List (Keith et al., 2011). 

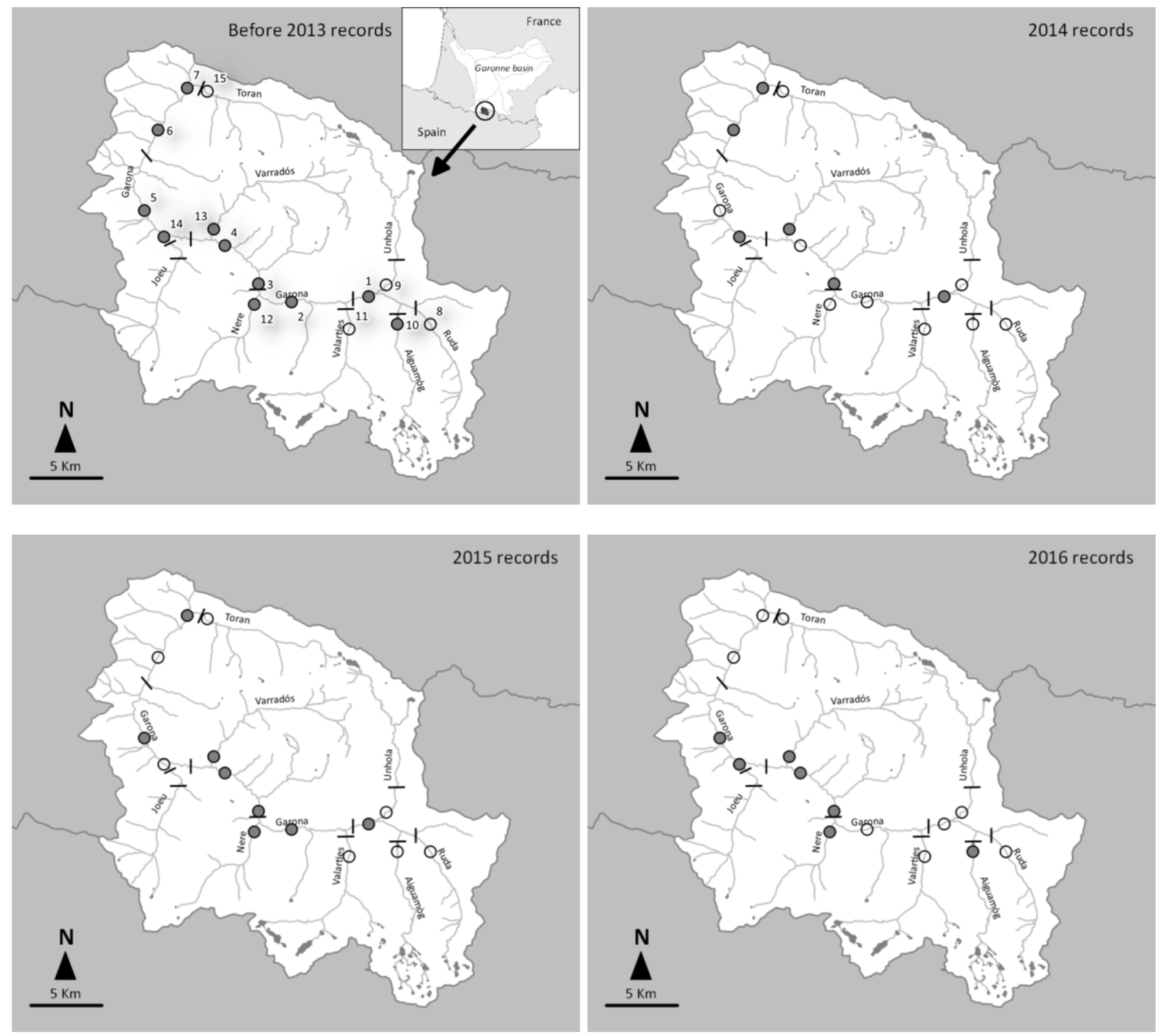

Fig. 1. Map of the Garonne drainage in the Val d'Aran (Catalonia, Spain) and location of the sampling sites (see codes in Tab. 1) showing the distribution area of Pyrenean sculpin Cottus hispaniolensis: $(\bigcirc)$ indicates sites with fish information data and (O) indicates sites where $C$. hispaniolensis is positively recorded. Physical barriers (weirs and dams) are marked as lines perpendicular to the river.

In June 2013, heavy rain combined with snow melting caused a severe spate in the Garonne River and its tributaries (the estimated return period is 50 years). According to data from the Bossòst gauging station $\left(42^{\circ} 47^{\prime} 1^{\prime \prime} \mathrm{N} ; 0^{\circ} 41^{\prime} 32^{\prime \prime} \mathrm{E}\right)$, flow discharge during the spate exceed $300 \mathrm{~m}^{3} \mathrm{~s}^{-1}$, whereas the mean discharge for the 1966-2013 period was $17.3 \mathrm{~m}^{3} \mathrm{~s}^{-1}$ (Ebro Water Authority; http://www.chebro.es/). The catastrophic spate induced dramatic changes in the streams morphology and its consequences produced an additional concern about the fate of Pyrenean sculpin. The aim of this study was to summarize existing data on the distribution and abundance of Pyrenean sculpin in the Spanish part of the Garonne drainage, and to provide information on the effects of the spate of 2013 on their populations.
Fish was sampled from 15 sites during summer and early autumn base flow conditions, from 2001 to 2016. Sampling sites $(80-200 \mathrm{~m}$ in length) were selected in relation to the historical range of Pyrenean sculpin, i.e. the main course of the Garonne River and the lower parts of its main tributaries (Fig. 1). Fish were captured by two pass electrofishing (pulsed DC). All captured fish were anaesthetized with clove oil, identified to species level, counted, measured (fork length $(\mathrm{FL}), \mathrm{mm})$, weighed $(\mathrm{g})$ and released at the same location after recovery. Population sizes $(N)$ of both Pyrenean sculpin and brown trout were estimated as $N=C_{1}^{2}\left(C_{1}-C_{2}\right)^{-1}$, where $C_{1}$ is the number of fish captured in the first sample and $C_{2}$ is the number of individuals caught in the second event; probability of capture was calculated as $p=\left(C_{1}-C_{2}\right)\left(C_{1}\right)^{-1}$ 
R. Rocaspana and E. Aparicio: Knowl. Manag. Aquat. Ecosyst. 2017, 418, 25

Table 1. Mean density, density range and percentage of occurrence of Pyrenean sculpin Cottus hispaniolensis in the sampling sites during the period 2001-2016. Information of sampling sites subjected to flow regulation is also included.

\begin{tabular}{llllccr}
\hline River & Code & Regulated & $N$ & Occurrence (\%) & Mean density \pm SD (ind. ha $^{-1}$ ) & Range (ind. ha $^{-1}$ ) \\
\hline Garonne & 1 & No & 5 & 83 & $167.8 \pm 167.4$ & $0-416.7$ \\
Garonne & 2 & Yes & 5 & 67 & $41.9 \pm 57.1$ & $0-138.9$ \\
Garonne & 3 & Yes & 5 & 100 & $130.8 \pm 111.6$ & $24.4-258.1$ \\
Garonne & 4 & Yes & 5 & 67 & $49.3 \pm 57.3$ & $0-133.3$ \\
Garonne & 5 & Yes & 5 & 67 & $49.1 \pm 54.7$ & $0-111.1$ \\
Garonne & 6 & Yes & 5 & 33 & $14.9 \pm 27.1$ & $0-44.4$ \\
Garonne & 7 & Yes & 4 & 60 & - & -5.9 \\
Ruda & 8 & No & 5 & 0 & $64.4 \pm 106.5$ & - \\
Unhola & 9 & No & 5 & 0 & - & $0-222.2$ \\
Aiguamòg & 10 & No & 4 & 60 & $107.8 \pm 135.5$ & - \\
Valarties & 11 & No & 5 & 0 & $288.5 \pm 146.2$ & $0-281.1$ \\
Nere & 12 & No & 4 & 60 & $306.1 \pm 388.1$ & $0-500.0$ \\
Varradò & 13 & No & 5 & 100 & - & $0-925.9$ \\
Joeu & 14 & No & 5 & 83 & 0 & - \\
Toran & 15 & Yes & 5 & 0 & \\
\hline
\end{tabular}

(Seber and Le Cren, 1967). Fish density (individuals ha ${ }^{-1}$ ) was calculated by dividing estimated number of fish by the area sampled. Because different sampling efforts were performed from 2001 to 2013 and not all sites were sampled annually, samples were time pooled as following: 2001-2005, 2006-2012, 2014, 2015 and 2016. After fish sampling, the streambed substrate was visually estimated (percentage composition) and classified according to a modified Wentworth scale: boulder (particle size $>256 \mathrm{~mm})$, cobble $(>64$ $256 \mathrm{~mm})$, pebble $(>16-64 \mathrm{~mm})$, gravel $(>2-16 \mathrm{~mm})$, sand $(0.1-2 \mathrm{~mm})$ and silt $(<0.1 \mathrm{~mm})$. Percent of the sampled reach that is pool, riffle, or run habitat was also recorded. Stepwise multiple linear regression was used to test the effect of habitat (substrate composition, channel units, and flow regulation) and biotic (mean brown trout density) predictors on mean sculpin density and occurrence. The significance level for predictor variables was 0.05 . Fish densities were $\log _{10}(x+1)$ transformed and percentage data were normalized using an arcsine square-root transformation.

Results showed that Pyrenean sculpin populations in the Spanish part of the Garonne drainage were scarce (Tab. 1), confined to localized areas of the streams, and most of them isolated due to the presence of artificial barriers (Fig. 1). Brown trout coexisted with Pyrenean sculpin, being dominant in density (brown trout mean density $\pm \mathrm{SD}=1988 \pm 1718$ ind. $\mathrm{ha}^{-1}$; range: $\left.63-7570 \mathrm{ind} . \mathrm{ha}^{-1}\right)$. The proportion of positive detections (namely range extension) of Pyrenean sculpin was progressively reduced from the $69.2 \%$ in the $2001-2005$ period to the $46.7 \%$ in 2016 . Mean densities also decreased over this period (Fig. 2). The natural disturbance caused by the severe spate of 2013 caused a marked reduction in distribution range and abundance. In 2014, after the spate, electrofishing surveys failed to find the species at several previously recorded sites and it was only present in $40.0 \%$ of the sampling sites. Also, mean density in 2014 was the lowest of the full period studied. In 2016, population density appeared to start a recovery trend (Fig. 2). The spate also had effects on the size structure, thus, in 2014 length-frequency distribution data (Fig. 3) showed a simplified structure, dominated by fish from 85 to $135 \mathrm{~mm}$ FL, and the $0+$ class $(<50 \mathrm{~mm})$ was very scarce. The spate occurred in sculpin spawning time (spring) and could damage the nests or flush down the newly hatched fry (Natsumeda, 2005). In 2015, the $0+$ class was also scarce probably because of a small stock of mature individuals in the reproductive season. In 2016, 3 years after the spate, length frequency distribution showed a substantial increase in the $0+$ class $(53.6 \%$ of the individuals). These results suggest that Pyrenean sculpin populations are resilient to severe spates, compensating for mortality with increasing recruitment in the following years.

The linear regression (stepwise procedure, $P<0.05$ ) revealed significant relationships of both sculpin density and occurrence with substrate composition, explaining the $78 \%$ of the difference in mean density and $72 \%$ of the difference in percentage of occurrence. Percent boulders, cobble and sand were positively related, with the first two having the strongest effect (Tab. 2); and the proportion of pools, runs and riffles, stream regulation, and brown trout density was not significantly related to sculpin density and occurrence. Our results are similar to those showed by Legalle et al. (2005a, 2005b) for sculpin populations in the French part of the Garonne drainage, where fish selected areas of coarse substrate where water velocity is weakened and sand accumulates.

Because Pyrenean sculpin populations currently exhibit lower densities with a reduced range and mostly fragmented, maintaining the status of Critically Endangered is advised. Our results indicated that some river sections were more suitable than others because consistently supported greater sculpin densities, being the presence of coarser substrate a significant factor. Therefore, the causes of the present situation may be related, at least in part, to a sub-optimal habitat quality. Main habitat alterations in the Garonne drainage are stream channelization and the presence of weirs and dams for hydroelectric purposes. Many channelization projects across 


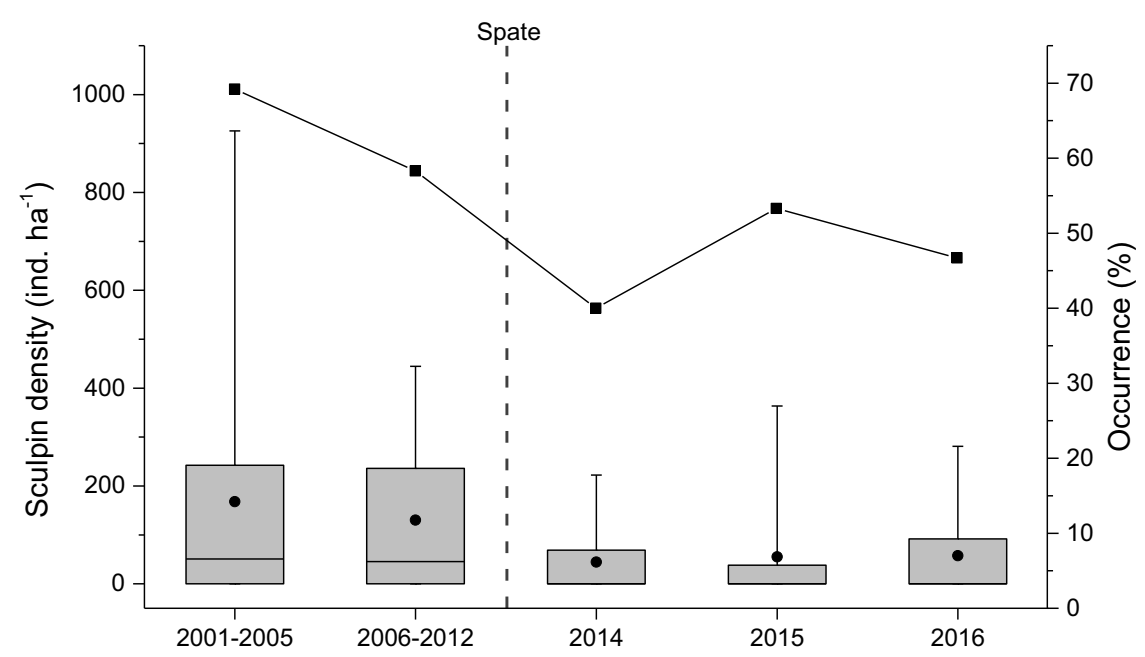

Fig. 2. Mean density (box-plots) and percentage of occurrence ( $\boldsymbol{\square}$ ) of Pyrenean sculpin Cottus hispaniolensis in the sampling sites from 2001 to 2016. Due to unequal sampling effort among years, data is pooled in several time groups. In box-plot, filled circle is the mean and solid horizontal line is the median. Upper and lower box limits are the 25 th and 75 th percentiles, and bars represent the 5 th and 95 th percentiles. The spate of June 2013 is represented as a dashed vertical line.
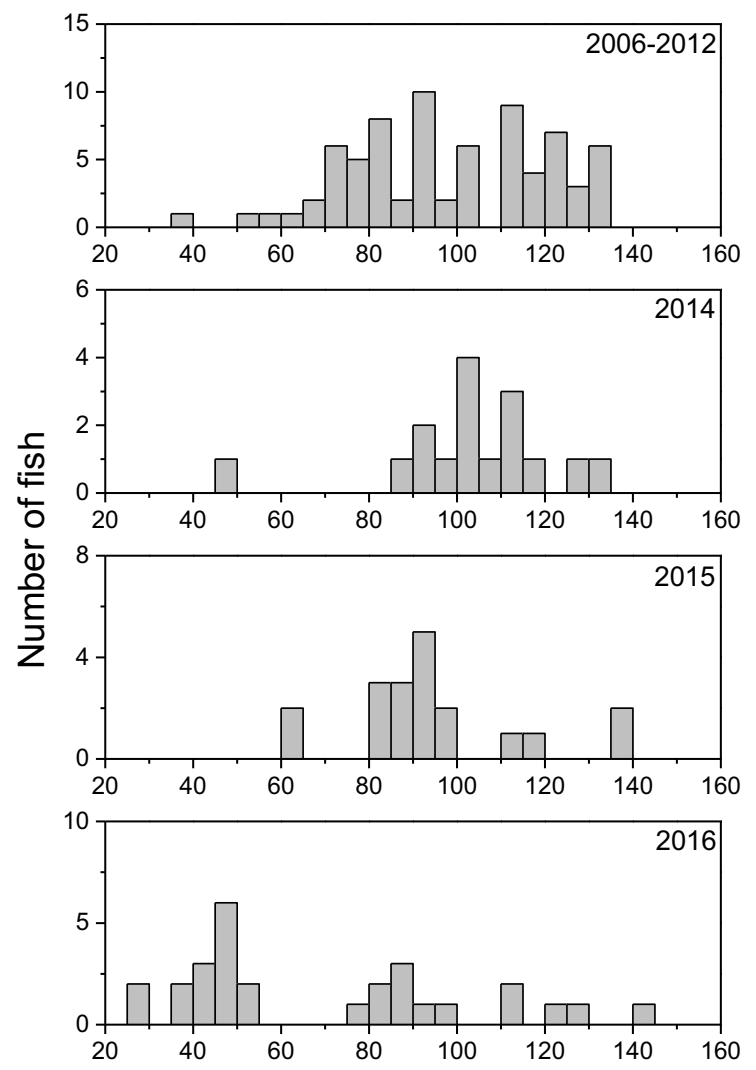

Fig. 3. Length-frequency distributions based on $5 \mathrm{~mm}$ FL classes of Pyrenean sculpin Cottus hispaniolensis sampled by electrofishing in the Spanish part of the Garonne drainage in the 2006-2012 period $(n=74), 2014(n=16), 2015(n=19)$ and $2016(n=28)$.

the drainage have been conducted in the last decades focused on infrastructures and urban areas protection. This type of habitat disturbance reduce the natural streams sinuosity (Brookes, 1994) and may alter the preferred microhabitat of
Table 2. Multiple linear regression models of mean density and percentage of occurrence of Pyrenean sculpin Cottus hispaniolensis based on habitat and biotic variables (see text). Models were created with stepwise multiple regressions (Adj. = adjusted; $\mathrm{RMSE}=$ residual mean square error). The significance level for inclusion of predictor variables was 0.05 .

\begin{tabular}{llllrr}
\hline Metric & Model & & Variable & Coefficient & \multicolumn{2}{l}{$P$} \\
\cline { 2 - 4 } & Adj. $R^{2}$ & RMSE & & & \\
\hline Density & 0.78 & \multirow{2}{*}{0.44} & Intercept & -8.178 & 0.0002 \\
& & & Boulders & 0.140 & $<0.0001$ \\
& & & Cobble & 0.123 & 0.0006 \\
& & & Sand & 0.056 & 0.0149 \\
Presence & 0.72 & \multirow{2}{*}{16.30} & Intercept & -281.870 & 0.0003 \\
& & & Boulders & 4.412 & $<0.0001$ \\
& & & Cobble & 4.581 & 0.0006 \\
& & & Sand & 2.178 & 0.0023 \\
\hline
\end{tabular}

Pyrenean sculpin, i.e. shallow littoral areas $(5-20 \mathrm{~cm}$ depth) and moderate current velocities $\left(<40 \mathrm{~cm} \mathrm{~s}^{-1}\right)$ with coarse substrate (Legalle et al., 2005a). Although our data did not show significant effects of flow regulation on sculpin density or occurrence, more research is needed since damming and flow regulation may adversely affect physical and hydraulic habitats, and therefore could reduce abundance and richness of fish and macroinvertebrate assemblages (Poff and Zimmerman, 2010).

Management actions that can be taken from the current analysis to strengthen sculpin populations include: (i) improve the knowledge of biological and ecological traits, together with the optimal habitat conditions in order to protect and improve the habitat quality, (ii) analysis of population genetic data since isolation and population bottlenecks may cause additional threats, and (iii) support declining populations with stocking, 
either from translocation of wild fish or cultured individuals. In accordance, a successful pilot project of captive breeding of Pyrenean sculpin was carried out in 2014 at a local fish culture centre. Mature fish (five females and four males) were captured in early spring from the Garonne River and placed in raceways (length $120 \mathrm{~cm}$, width $50 \mathrm{~cm}$, and depth $20 \mathrm{~cm}$ ) with ceramic roof tiles distributed on the bottom as shelter. Successful spawning occurred at the artificial substrates and $\mathrm{ca} .180$ cultured sculpins were released in the wild in October 2014. However, this action is beginning and further actions are needed to be implemented.

Acknowledgments. Financial support was provided by the Conselh Generau d'Aran, Fundación Biodiversidad, ENDESA and Project LIFE LimnoPirineus (NAT/ES/001210). The authors are grateful to Ivan Afonso (Biodiversity Service, Conselh Generau d'Aran), Antoni Palau (University of Lleida), Quim Pou-Rovira (Sorelló-LIFE LimnoPirineus) and Dolors Vinyoles (University of Barcelona) for their support and collaboration. We also thank Eloi Cruset, Alvaro Pujals and the squad of forest rangers from the Conselh Generau d'Aran, who helped us during field work, Dr. Carles Alcaraz and two anonymous referees for valuable comments on the manuscript. All appropriate ethics and permissions required for the realization of this manuscript were obtained, previously, by the authors.

\section{References}

Aparicio E. 2015. First record of a self-sustaining population of Alpine charr Salvelinus umbla (Linnaeus. 1758) (Actinopterygii, Salmonidae) in Spain. Graellsia 71: e034.

Aparicio E, Alcaraz C, Carmona-Catot G, et al. 2016. Peixos continentals de Catalunya. Ecologia, conservació i guia d'identificació. Barcelona: Lynx Edicions, 251 p.
Brookes A. 1994. River channel change. In: Calow P, Petts GE, eds. The Rivers Handbook, Vol. 2. Oxford: Blackwell Scientific Publications, pp. 55-75.

de Sostoa A, Allué R, Bas C, et al. 1990. Peixos (Història Natural dels Països Catalans). Barcelona: Enciclopèdia Catalana, $487 \mathrm{p}$.

Doadrio I, Perea S, Garzón-Heydt P, González JL. 2011. Ictiofauna continental española - Bases para su seguimiento. Madrid: Ministerio de Medio Ambiente y Medio Rural y Marino, 610 p.

Freyhof J, Kottelat M, Nolte A. 2005. Taxonomic diversity of European Cottus with description of eight new species (Teleostei: Cottidae). Ichthyol Explor Freshw 16: 107-172.

Keith P, Persat H, Feunteun E, Allardi J, coords. 2011. Les poissons d'eau douce de France, Biotope Éditions. Paris: Mèze - Museum national d'Histoire naturelle, $552 \mathrm{p}$.

Legalle M, Mastrorillo S, Santoul F, Céréghino R. 2005a. Ontogenetic microhabitat shifts in the bullhead, Cottus gobio L., in a fast flowing stream. Int Rev Hydrobiol 90: 310-321.

Legalle M, Santoul F, Figuerola J, Mastrorillo S, Céréghino R. 2005b. Factors influencing the spatial distribution patterns of the bullhead (Cottus gobio L., Teleostei Cottidae): a multi-scale study. Biodivers Conserv 14: 1319-1334.

Natsumeda T. 2005. Biotic and abiotic influences on nest-hatching outcome in the Japanese fluvial sculpin Cottus pollux. Environ Biol Fish 74: 349-356.

Poff NL, Zimmerman JKH. 2010. Ecological responses to altered flow regimes: a literature review to inform the science and management of environmental flows. Freshw Biol 55: 194-205.

Seber GAF, Le Cren ED. 1967. Estimating population parameters from catches large relative to the population. J Anim Ecol 36: 631-643.

Sousa-Santos C, Robalo JI, Pereira A, Doadrio I. 2014. Threatened fishes of the world: Cottus hispaniolensis Bacescu-Mester, 1964 (Cottidae). Croatian J Fish 72: 132-133.

Tomlinson ML, Perrow MR. 2003. Ecology of the Bullhead. Conserving Natura 2000 Rivers, Ecology Series No. 4. Peterborough: English Nature, $16 \mathrm{p}$.

Cite this article as: Rocaspana R, Aparicio E. 2017. Population trends and current status of the endangered Pyrenean sculpin Cottus hispaniolensis in the Spanish part of the Garonne drainage. Knowl. Manag. Aquat. Ecosyst., 418, 25. 